\title{
Short Communication: Species diversity of corticolous lichens in the arboretum of Padjadjaran University, Jatinangor, Indonesia
}

\author{
JOKO KUSMORO ${ }^{1}$, BETTY MAYAWATIE ${ }^{1}$, RULLY BUDIONO ${ }^{1}$, IIN SUPARTINAH NOER ${ }^{1}$, \\ RIRIN EKA PERMATASARI ${ }^{2}$, ALISA NURWAHIDAH ${ }^{1}$, RIKA SATRIAWATI ${ }^{1}$, DIAH ARUM ${ }^{1}$, \\ DORA ERAWATI SARAGIH ${ }^{1}$, RIA WIDYA ${ }^{1}$, MUHAMAD FEISAL JATNIKA ${ }^{1}$, AFIF MAKARIM ${ }^{1}$, \\ RUHYAT PARTASASMITA ${ }^{1, \bullet}$ \\ ${ }^{1}$ Department of Biology, Faculty of Mathematics and Natural Sciences, Universitas Padjadjaran. Jl. Raya Bandung Sumedang Km. 21, Jatinangor, \\ Sumedang 45363, West Java, Indonesia. Tel.: +62-22-7796412, Fax.: +62-22-7796412, "email: rp2010rikkyo@ gmail.com; \\ ruhyat.partasasmita@unpad.ac.id; kusmorojoko@gmail.com. \\ ${ }^{2}$ Program of Environmental Science, Faculty of Postgraduate, Universitas Padjadjaran. Jl. Sekeloa Selatan I, Bandung 40134, West Java, Indonesia.
}

Manuscript received: 27 December 2018. Revision accepted: 15 May 2019.

\begin{abstract}
Kusmoro J, Mayawatie B, Budiono R, Noer IS, Permatasari RE, Nurwahidah A, Satriawati R, Arum D, Saragih DE, Widya R, Jatnika MF, Makarim A, Partasasmita R. 2019. Short Communication: Species diversity of corticolous lichens in the arboretum of Padjadjaran University, Jatinangor, Indonesia. Biodiversitas 20: 1606-1616. The lichen flora of tropical areas is still much under explored, Java in general and the Arboretum in West Java in particular, are no exceptions. The Arboretum of the main campus of Padjadjaran University, Jatinangor, Sumedang, West Java, Indonesia is representative of a typical man-made lowland tropical rain forest ecosystem in Java. It is planted with peculiar and rare species of plants, such as Antidesma bunius, Syzygium cumini, Durio zibethinus, Caesalpinia pulcherrima, Tectona grandis, Albizzia falcataria, Swietenia mahagoni, Alstonia scholaris, Jatropha multifida, Sterculia foetida, Diospyrus blancoi, Hura crepitans and Rauvolfia serpentina. We explored the lichen flora of this Arboretum using species of corticolous macrolichens as indicator taxa. Lichen survey was performed by exploring the different zones, such as zones for rare species, industrial plants, medicinal plants and fruit plants. Lichen diversity on 23 trees spread in 12 ha area was documented based on morphological and anatomical features, and also chemical tests. A total of 68 species of lichens, distributed in 38 genera and 12 families, were enumerated during the study. The crustose and foliose forms contributed 62\% (42 species) and 37\% (25 species) of the total species, respectively. Graphidaceae with 28 species and Parmeliaceae with 15 species were the dominant families, which together constituted more than 50\% of the lichen populations. Graphis librata and Parmeliopsis sp. were the dominant and co-dominant species and Drinaria picta was another common species.
\end{abstract}

Keywords: Arboretum, corticolous lichens, species diversity

\section{INTRODUCTION}

Lichens are a highly diverse group of mutualistic organisms consisting of a fungal (the mycobiont) and a photosynthetic algal partner (the photobiont) living in a symbiotic association with each other to form a discrete structure (the thallus). The lichen thallus is a relatively stable and well-balanced system that has distinct structure and morphology that is often species-specific. The photobiont contains chlorophyll and may be either a member of the chlorophyta (green algae) in about $90 \%$ or a cyanobacterium (blue-green algae) in about $10 \%$ of the total lichens (Rogers 1992). In the lichen association, the photobiont provides the energy for maintaining life and growth of the structure, while the mycobiont offers protection to the photobiont by reducing the light intensity to which the photobiont is exposed and is also thought to enhance water uptake (Nash 2008).

Lichens constitute a significant portion of forest biodiversity worldwide (McCune 2000; Debolt et al. 2007), forming a cover of about $8 \%$ of the earth's terrestrial surface (Purvis 2000; Brodo et al. 2001). Globally, there are an estimated 14,000 species of lichens (Brodo et al. 2001). While lichens are generally believed to be more diverse in cool temperate climates, studies indicate that lichen diversity in the tropics may equal or even surpass that found in non-tropical areas (Lücking 1999). Tropical montane forests are typically characterized by a high diversity of epiphytes, both of higher plants and lichens (Gradstein et al. 1996; Komposch and Hafellner 2000; Lücking and Matzer 2001). However, little is known about their diversity in the tropical areas due to limited studies and lack of inventory data for most such areas. Consequently, large areas, especially the paleo tropics, remain mostly under-explored making it difficult to make accurate estimates of lichen diversity (Lücking 1999; Lücking and Matzer 2001; Feuerer and Hawksworth 2006; Caceres et al. 2008a; Lücking et al. 2009).

Our current knowledge of lichens in Indonesia is among the poorest in the world and studies in lichen diversity and its ecology are rare. Alexander Zahlbruckner has released "lichen flora of Java" in 1943. Noer (1989) attributed the 
limited studies of lichens in Kamojang, Gunung Salak and Darajat Geothermal field of West Java to the lack of lichen expertise in the region and reference materials, and also to the fact that most botanists in Indonesia prefer to work on vascular plants. Recent studies in the tropical regions are revealing a much higher diversity than previously envisaged (Caceres et al. 2008a,b). In a recent publication of one hundred new species of lichenized fungi, Lumbsch et al. (2011) placed the estimates of the undescribed lichens at about 10,000 species, most of which are likely to be found in the tropical areas of the world. For complete global lichen diversity, more focus should therefore be placed on the tropical regions, especially on the primary forests (Sipman and Aptroot 2001).

Corticolous lichens grow epiphytically on the bark of trees and shrubs, forming one of the most striking characteristics of tropical montane forests (Gradstein et al. 2003). They play an important role in water balance and nutrient cycle in these forests; their value is exemplified by their usefulness as ecological indicators of climate and forest type (Brodo et al. 2001; Gradstein et al. 2003; Aptroot and van Herk 2007). As such, describing and analyzing these communities is a research priority for conservation of biodiversity and a prerequisite for sustainable management of tropical montane forests (Holz and Gradstein 2005).

This study is aimed at enhancing our current knowledge on the diversity of lichens in the tropics by assessing the distribution of the corticolous lichens along an altitudinal gradient in Arboretum of Padjadjaran University, Jatinangor, Indonesia. The lichen diversity data thus obtained will constitute an important baseline information for future use in biomonitoring studies.

According to Kershaw (1985), environmental conditions such as climate, substrate, light and moisture play important roles in the distribution of lichen. Lichen species with similar distribution models tend to have similar ecological requirements. Monitoring programs by lichen research that are more specific to environmental monitoring are needed to ensure that the moss ecosystems are conserved and managed sustainably to maintain their environmental benefits in the ecosystems. Unfortunately, in the case of Arboretum of Padjadjaran University main campus, Jatinangor, Sumedang, West Java, Indonesia there are no studies regarding lichen diversity and distribution that are necessary to catch the attention of the concerned public agency in the government. Assessment of these organisms is the effective tool to provide information for efficient environmental monitoring.

\section{MATERIALS AND METHODS}

\section{Study area}

The Padjadjaran University (Unpad) main campus, Jatinangor is lying in the foot of Mount Geulis and Mount Manglayang, at an elevation of $720-820 \mathrm{~m}$. The coordinates are $107^{\circ} 77^{\prime} 20^{\prime \prime} \mathrm{E} ; 6^{\circ} 93^{\prime} 252^{\prime \prime} \mathrm{S}$, located in the direction of Bandung city with a straight distance of $22.75 \mathrm{~km}$. Administratively, it is a part of the Hegarmanah Village, Jatinangor sub-district, Sumedang district, West Java Province, Indonesia.

The study site arboretum is located at an altitude of 723-750 meters above sea level, in coordinates of $107^{\circ} 46^{\prime} 14.13^{\prime \prime}-107^{\circ} 46^{\prime} 28.80^{\prime \prime} \mathrm{E}$ and 6 ${ }^{\circ} 55^{\prime} 34.41^{\prime \prime}$ $6^{\circ} 55^{\prime} 54.92$ " S. The total area Arboretum of campus is 12.5 ha. The present study was carried out from June 2018 to November 2018, in selected locations. The location map of the study is presented as Figure 1.

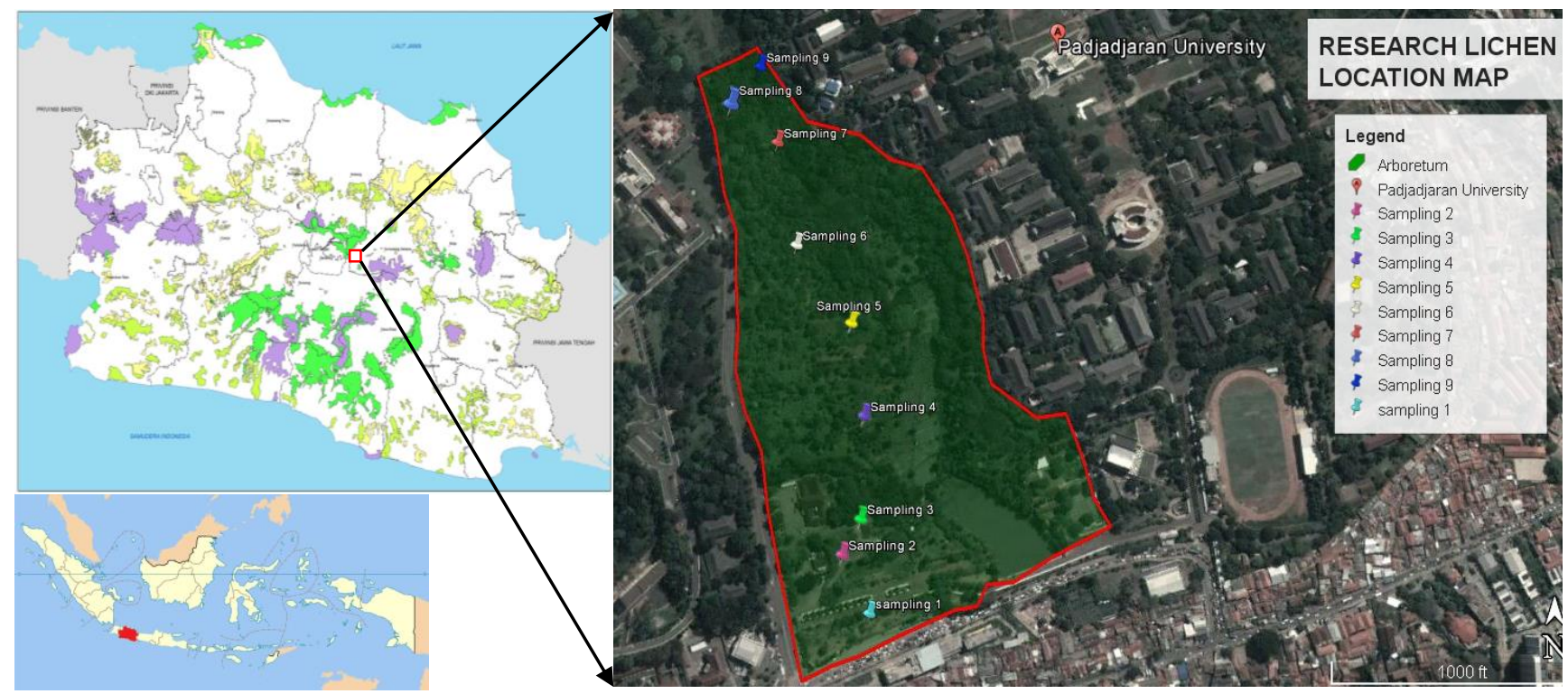

Figure 1. Locations of lichen study in the arboretum of Padjadjaran University, main campus, Jatinangor, Indonesia 


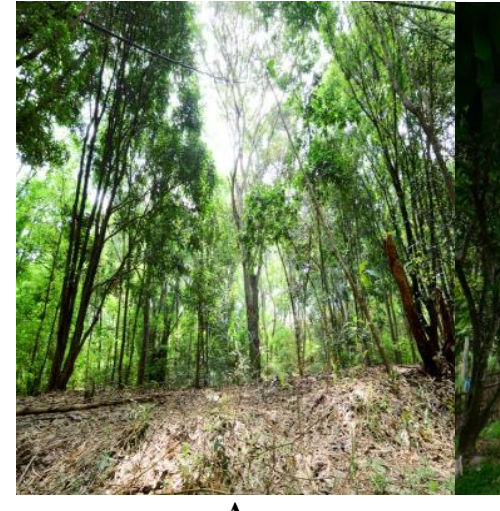

A

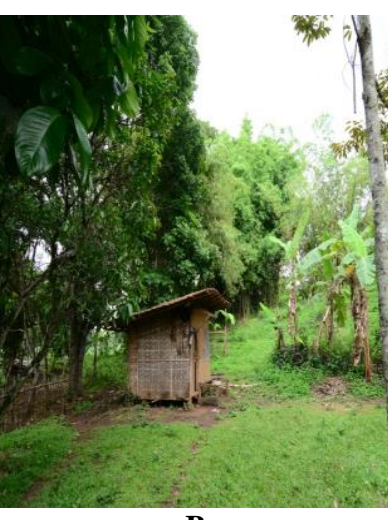

B

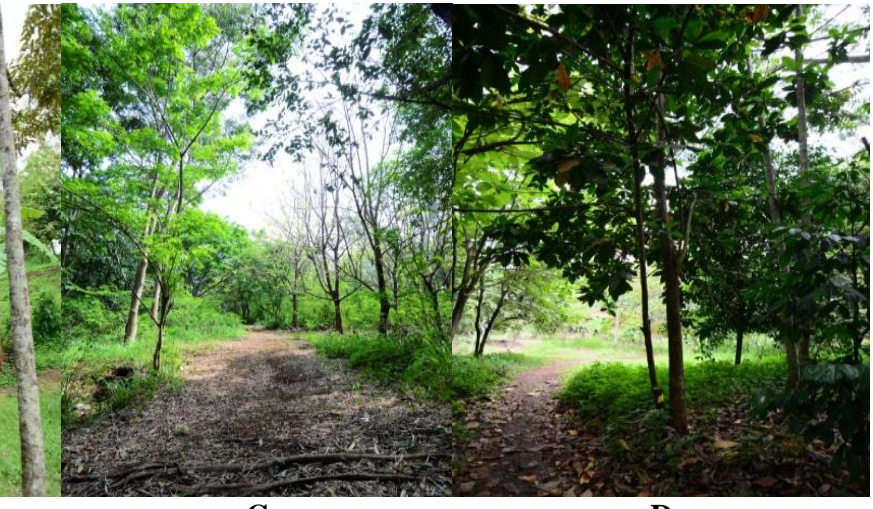

C
D

Figure 2. Different zones of the arboretum: A. Rare species Zone, B. Village ecosystem zone, C. Industrial plants zone, D. Identity plants zone

The Unpad campus at Jatinangor has a campus forest that is cultivated whose ecosystem is similar to native forests. The campus forest area is 62.59 ha of which an area of 24.45 ha is an arboretum. The arboretum is divided into several zones planted with various types of plants in accordance with taxonomic criteria, village ecosystem zones and regional identity categories of West Java Province. The zones of arboretum includes fruit plant zone, industrial plant zone, medicinal plant zone, rare plant zone and zone of symbollic plants of the districts (jatidiri plants) of West Java (Figure 2).

In general, the study area has man made forest formations dominated by plant species, such as tahiti chestnut (Inocarpus fagifer), chinquapin (Castanopsis argentea), sea mango (Cerbera manghas), rasamala (Altingia excelsa), bignay (Antidesma bunius), schleichera (Schleicera oleosa), calabash (Crescentia cujete), jambolan (Syzygium cumini), rukem (Flacourtia rukam), canistel (Pouteria campheciana), elemi (Canarium commune), african tuliptree (Spathodea campanulata), jamaica cherry (Muntingia calabura), monkey pod tree (Samanea saman), bamboo (Schizostachyum blumei), Litsea fulva, common red stem fig (Ficus variegata), poison fish tree (Barringtonia asiatica), cerlang (Pterospermum javanicum), white cheese wood (Alstonia scholaris), kiteja (Neolitsea javanica), Indian snake root (Rauvolfia serpentina), Cinnamomum sintoc, velvet apple (Diospyros blancoi) and Alyxia reinwardtii.

\section{Climate}

The region has tropical, warm and humid climate with two principle seasons - dry and wet season. Dry season is severe, extending from April to August while wet season starts from early September extending up to May. The temperature is 29.7 to $30.9^{\circ} \mathrm{C}$ on wet season and humidity is high throughout the year, with an average of $87 \%$ during morning and $70 \%$ during evening. Rainfall averages between 600 and $1000 \mathrm{~mm}$ per annum, and light intensity ranges from 3300 to 43200 lux.

Dominant wind direction and $\mathrm{d}$ wind speed based on secondary data windrose BMKG Banung class I can be conclude that the dominant wind direction is from west to east. The wind speed is 1-4 knots with a percentage of $4 \%$.

\section{Collection and identification of lichens}

Documentation of diversity of lichens was carried out by land survey method by exploring an area of 12.35 ha starting from the ecosystem near the check dam through the zone of industrial plants, zone of rare species, village ecosystem zone, identity plants zone, and then return to garden plants in check dam area.

In each zone, 4-5 trees with a minimum of $30 \mathrm{~cm}$ diameter at breast height (DBH) were randomly selected for sampling lichens. The corticolous lichen specimens observed on the selected trees were collected with the help of a chisel and hammer, along with recording of ecological notes, which includes the host tree type and altitude. The collected specimens were investigated morphologically, anatomically and chemically for further identification (Kumar 2009b). The specimens were placed on a hard card sheet and packed in a lichen herbarium packet $(17 \mathrm{~cm}$ $\mathrm{x} 10 \mathrm{~cm}$ ) with details of the locality, and preserved in the herbarium of the Department of Biology, Faculty of Mathematics and Natural Science, University of Padjadjaran, Jatinangor, Sumedang, West Java, Indonesia (Obermayer 2002).

Morphological features were studied under stereo microscope (Olympus CX22) with $10 \mathrm{x}$ to $45 \mathrm{x}$ magnifications and anatomical features were studied under light microscope XSZ-107BN with $40 \mathrm{x}$ to $400 \mathrm{x}$ magnifications, using optilab microscope camera. Thin hand-cut sections of thalli and ascomata mounted in water were observed.

Thalline spot test was applied for identifying lichen species that have a color reaction using $10 \%$ solution of Potassium hydroxide and $4 \%$ solution of Sodium hypochlorite or chlorine. Microcrystal test was performed by using crystallizing reagents: GE (glycerine-acetic acid), GAW (glycerine alcoholwater), GAoT (glycerine alcohol o-toluidin) and GAAn (glycerine alcohol aniline) (Hale 1974; Huneck and Yoshimura 1996).

The species of collected lichens were identified by comparing them with the characteristics given in Schumm and Aptroot (2010), Zahlbrukner (1843), and Lucking et al. (2009). 


\section{RESULTS AND DISCUSSIONS}

\section{Species diversity of lichens}

Species richness is the number of species found in each substrate in the area observed (Odum 1993). The results of the study indicated that lichen diversity of the Arboretum (Unpad) of Jatinangor campus consisted of 68 species, belonging to 38 genera and 12 families (Tabel 1). Mostly they are belonging to the group Ascomycetes. The crustose and foliose forms contributed $62 \%$ (42 species) and 37\% (25 species) of total species, respectively. Graphidaceae with 28 species and Parmeliaceae with 15 species were the dominant families, which together constituted more than $50 \%$ of total lichen populations. Graphis librata and Parmeliopsis sp. were the dominant and codominant species. Drinaria picta was another frequently encountered species.

Eight species of trees were found in the study locations which were preferred by lichens as their habitat. They were common guajava (Psidium guajava), chinese petai (Leucaena leucocephala), neem tree (Azadirachta indica), surian (Toona sureni), mahogany (Swietenia mahagoni), narra (Pterocarpus indicus), kapok (Ceiba petandra), and avocado (Persea americana).

The results of the literature search revealed that the Graphidaceae tribe has more than 1000 recorded species globally and most of them were growing in tropical rainforests or subtropical forests.-Generally, lichens of the Graphidaceae tribe prefers tree bark as the substrate/place to grow than rock or soil (Staiger 2005). A special feature of this tribe is the white to grayish colored crustose thallus with elongated fruiting body (lirellae). The best known species is Graphis librata which was found in trees that grow in the green lane of the study area.

Graphis is a genus of lichenized fungi in the family Graphidaceae. According to the Krik et al. (2008), this widespread genus contains 386 species. Graphidaceae is one of the most prevailing group in lichen communities, though its classification is not well developed.

Six species of Graphidaceae which are very often found in the arboretum are: Graphis sp 2, Acanthothecis claulifera, Glyphis scyphulifera, Graphis librata, Platygramme discurrens and Thecaria quassilicola. The total species diversity of this genera in the arboretum area consists of 12 species, and is almost the same as that found in the geothermal area of Kamojang, West Java (Kusmoro et al. 2018), but is far more diverse than Thailand. Only 32 species of Graphis have been reported from the entire Thailand (Pitakpong et al. 2016). Graphis has a higher probability of distribution at medium altitude than in high and low regions in Thailand, while arboretum at Jatinangor is located at an altitude of about $700 \mathrm{~m}$ asl. Changes in environmental conditions can affect their growth. If habitat of Graphis is lost or changed, its populations may disappear completely. These findings are important for effective lichen conservation in the arboretum (Unpad) of Jatinangor Campus. At present, climate change may be the major cause for the loss of lichens from the study area.

Graphidaceae spreads mainly in tropical and subtropical regions. Graphis is the largest tropical crustoce mrolinene genus, a group that has been ignored but contributes a large part of the diversity of tropical lichen biota (Rivas Plata et al. 2012). In Thailand, the genus Graphis generally grows in the forest.

Crustose lichens have morphological properties in the form of crust and they do not require much water, which allows these lichens to grow easily. The current study results showed that diversity of crustose lichens was more than foliose lichens. Lichens of crustose type are considered more tolerant to air pollution because they have relatively simpler thallus structure compared to other lichen types (McCune 2006).

The type of lichens often found in the arboretum are Parmotrema tinctorum, Graphis emersa, Cryptothecia, Lecanora helva and Phaeographis sp. These type of likhens are able to tolerate conditions of pollution (State et al. 2010; Vicol 2016; Richardson 1992). Collema types of lichens are found near the Dam check and ditch, which is an indicator of the presence of moist areas.

Some of the important lichens found in the study area are shown in Figures 3-12, with brief descriptions. Members of Lecanoraceae with gray-yellow thallus and apothecia appearing to be clear. Spores single (Figure 3). It is a member of Arthoniaceae. This type of lichen has a green crustose thalus and a bright red lirellae. Spores consist of 4-5 transverse septa (Figure 4). A member of Caliciaceae. It has a transverse septae of apothecia, is black, rather wide. Color of thalus is grayish green (Figure 5). It is a member of Parmeliaceae and has a foliose thalus. Grayish color on upper surface and brown lower surface. Found in Mahoni uganda trees (Figure 6). It is a member of Parmeliaceae. There is wrinkling in the middle of the thallus and lot of soredia on the edges of the lobe that is located in the middle of the thallus (Figure 7). It is a member of Parmeliaceae which has a green thalus with a lobe bent inward on the upper surface of the thallus, and rhizin on the lower surface (Figure 8). Thallus is diffuse, rather thick, powdery (leprose) crust, pale to greenish bluegrey, with a white medulla, granules commonly with a weft of projecting cottony hyphae; apothecia unknown. Trebouxia is the phycobiont. Found on trunks of duren, kemiri, kamboja, sukun, and jati, especially where sheltered from direct rain, widespread and evidently common (Figure 9). Thallus thin, leprose and granularsorediate, sometimes diffuse, bright yellow; apothecia apparently unknown, minute, with orange but yellowpruinose discs. Found on tree bark of Suren, palem raja and jati putih. Phytobiont: Trebouxia and Trentepohlia (Figure 10). Thallus green, medulla is white, isidia is not found in this species. Trentepohloid is the photobiont. Secondary metabolites consist of atranorin. Found on flamboyant trees (Delonix regia), suren (Toona sp.), beringin (Ficus benjamina) and duren (Chrysophyllum cainito) (Figure 11). Thallus grayish green with a fairly smooth texture. Lirellae is black, elongated but small, rather slender, flat, hollow, and has white margins. The apothecia incision is blackish brown. Spores consist of 8-transverse septa with 9 locules. Secondary metabolites consist of atranorin. Found on mindi trees (Melia azedarach) (Figure 12). 
Table 1. Lichen diversity in Arboretum of Padjadjaran University, Jatinangor, Indonesia

\begin{tabular}{|c|c|c|c|c|c|}
\hline Species & Family & Plants where lichens grow (habitat) & Reproduction & Lichenic acid & $\begin{array}{l}\text { Growth } \\
\text { form }\end{array}$ \\
\hline Acanthothecis sp. & Graphidaceae & Switenia mahagoni, Ficus variegata & Lirallae & Atranorin & Crustose \\
\hline Amandinea melaxanthella $(\mathrm{Nyl}) \mathrm{Marbach}$ & Caliciaceae & Persea americana, Artocarpus heterophyllus, Maesopsis eminii & Apothecia & Atranorin & Crustose \\
\hline Anomalographis madeirensis (Tav.) Kalb. & Graphidaceae & Artocarpus heterophyllus & Lirellae & Atranorin & Crustose \\
\hline Arthonia antillarum (DC.) Walf & Arthoniaceae & $\begin{array}{l}\text { Pinus merkusii, Gmelina arborea, Persea americana, Annona } \\
\text { muricata }\end{array}$ & Apothecia & $\begin{array}{l}\text { Chlooatranorin, atranorin, } \\
\text { gyrophoric }\end{array}$ & Crustose \\
\hline Arthonia sp. & Arthoniaceae & Leucaena leucocephala & Apothecia & - & Crustose \\
\hline Buellia subdisciformis (Leighton) Jatta & Caliciaceae & Persea americana, Switenia mahagoni & Apothecia & Atranorin & Crustose \\
\hline $\begin{array}{l}\text { Carbacanthographis candidate (Nyl.) } \\
\text { Staiger \& Kalb }\end{array}$ & Graphidaceae & $\begin{array}{l}\text { Euphoria longan, Persea americana, Parkia speciosa, Artocarpus } \\
\text { heterophyllus }\end{array}$ & Lirallae & Atranorin & Crustose \\
\hline $\begin{array}{l}\text { Carbacanthographis marcescens (Fée) } \\
\text { Staiger \& Kalb }\end{array}$ & Graphidaceae & Manilkara zapota & Lirellae & Atranorin & Crustose \\
\hline Chapsa leprieurii (Mont.) & Graphidaceae & Durio zibethinus & Lirellae & Atranorin & Crustose \\
\hline Collema nigrescens (Huds.) DC & Collemataceae & Gmelina arborea, & Isidia & - & Foliose \\
\hline Cryptothecia sp. 1 & Arthoniaceae & Delonix regia, Toona sureni, Ficus variegata, Chrysophyllum cainito & - & Atranorin & Leprose \\
\hline $\begin{array}{l}\text { Diorygma hieroglyphicum (Pers.) Staiger \& } \\
\text { Kalb }\end{array}$ & Graphidaceae & Switenia mahagoni & & & Crustose \\
\hline Dirinaria applanata (Fée) D.D.Awasthi . & Caliciaceae & $\begin{array}{l}\text { Chrysophyllum cainito, Persea americana, Morinda citrifolia, } \\
\text { Roystonea regia, Ceiba petandra, Acacia mangium }\end{array}$ & $\begin{array}{l}\text { Apothecia, } \\
\text { soredia }\end{array}$ & $\begin{array}{l}\text { Atranorin, barbatic, } \\
\text { isousnic }\end{array}$ & Foliose \\
\hline Dirinaria sp. & Caliciaceae & Leucaena leucocephala & Soredia & - & Foliose \\
\hline Dyplolabia afzelii (Ach) A. Massal & Graphidaceae & Switenia mahagoni & Lirallae & Atranorin & Crustose \\
\hline Glyphis scyphulifera (Ach.) Staiger & Graphidaceae & Persea americana & Lirallae & Atranorin & Crustose \\
\hline Glyphis substriatula (Nyl.) Staiger. & Graphidaceae & Manilkara zapota & Lirellae & Atranorin & Crustose \\
\hline Graphis sp.1 & Graphidaceae & Leucaena leucocephala, Roystonea regia & Lirallae & Atranorin & Crustose \\
\hline Graphis sp. 2 & Graphidaceae & Leucaena leucocephala, Corypha utan & Lirallae & - & Crustose \\
\hline Graphis sp.3 & Graphidaceae & Toona sureni, Wodyetia bifurcata & Lirallae & Salazinic & Crustose \\
\hline Graphis sp.4 & Graphidaceae & Switenia mahagoni & Lirallae & - & Crustose \\
\hline Graphis duplicata Ach. & Graphidaceae & Persea americana & Lirallae & Atranorin & Crustose \\
\hline Graphis elongata Zenker & Graphidaceae & Persea americana & Lirallae & Atranorin & Crustose \\
\hline Graphis emersa Mull. Arg. & Graphidaceae & Melia azedarach & Lirallae & Atranorin & Crustose \\
\hline Graphis insulana (Mull. Arg) Luking & Graphidaceae & Switenia mahagoni, Artocarpus heterophyllus & Lirallae & Atranorin & Crustose \\
\hline Graphis intricata Fée & Graphidaceae & Switenia mahagoni, Euphoria longan, Ceiba petandra & Lirallae & Atranorin & Crustose \\
\hline Graphis librata C. Knight & Graphidaceae & Corypha utan, Delonix regia & Lirallae & Atranorin & Crustose \\
\hline $\begin{array}{l}\text { Graphis longispora D.D. Awasthi \& S.R. } \\
\text { Singh }\end{array}$ & Graphidaceae & Mangifera indica & Lirallae & Atranorin & Crustose \\
\hline Graphis urandrae Vain. & Graphidaceae & Mangifera indica & Lirallae & - & Crustose \\
\hline
\end{tabular}


Hemithecium implicatum (Fee) Staiger

Heterodermia obscurata $\mathrm{Nyl}$.

Lecanora $\mathrm{sp} .1$

Lecanora sp. 2

Lecanora helva Stizenb

Lepraria candelaris (L.) Fr., Nov. Sched.

Critic. Lich

Lepraria incana (L.) Ach.

Leptogium cyanescens (Rabenh.) Korb

Melanotrema meiospermum (Nyl.) Frisch

Ochloroea sp.

Opegrapha paraxanthodes $\mathrm{Nyl}$

Parmelia sp.1

Parmelia sp. 2

Parmeliopsis sp.

Parmotrema sp.1

Parmotrema gardneri (C.W. Dodge) Serus Parmeliaceae Parmotrema perforatum (Wulfen) A.Massal. Parmeliaceae

Parmotrema sorediata Müll. Arg.

Parmotrema sp. 1

\section{Parmotrema sp.2}

Parmotrema sp. 3

Parmotrema sp.4

Parmotrema sp.5
Parmeliaceae

Parmeliaceae

Parmeliaceae

Lecanoraceae

Lecanoraceae

Stereocaulaceae

Stereocaulaceae

Collemataceae

Thelotrematacea

Roccellaceae

Parmeliaceae

Parmeliaceae

Parmeliaceae

Parmeliaceae

Parmeliaceae

Parmeliaceae
Persea americana, Plumeria sp., Delonix regia, Khaya antotheca, Lirallae Ceiba petandra

Persea americana

Roystonea regia, Leucaena leucocephala

Roystonea regia, Leucaena leucocephala

Honduras Mahogany, Morinda citrifolia, Persea americana

Toona sureni, Roystonea regia, Gmelina arborea

Apothecia

Apothecia

Apothecia

Durio zibethinus, Aleurites moluccanus, Plumeria sp., Artocarpus communis, Durio zibethinus, Tectona grandis

Switenia mahagoni

Melia azedarach,Ceiba petandra

Toona sureni

Toona sureni, Switenia mahagoni, Leucaena leucocephala

Switenia mahagon

Persea americana

Apothecia

Apotheci

Lirellae

Soredia

Soredia

Soredia

Khaya antotheca

Toona sureni

Mangifera indica

Acacia mangium, Switenia mahagoni

Acacia mang ium, Switenia mahagoni, Ceiba petandra, Roystonea regia

Acacia mangium, Switenia mahagoni, Ceiba petandra, Roystonea Soredia regia

Switenia mahagoni, Acacia mangium

Soredia

Pterocarpus indicus, Switenia mahagoni, Acacia mangium, Persea Soredia americana

Khaya antotheca, Cocos nucifera

Soredia
Atranorin

Crustose

Atranorin, alectoronic, Foliose hypoprotocetraric

Atranorin

Atranorin

Atranorin

Atranorin

Crustose

Atranorin, gyrophoric Crustose

Atranorin, physodic,

hypoprotocetraric,

miriquidic,

haemathamnolic -

Foliose

isousnic

Atranorin, usnat

Foliose

Atranorin,

Foliose

chloroatranorin, psoromic,

retigeric,

pseudoplacodiolic, didymic

Anziaic, diffractaic,

nephroarctin isousnic,

psoromic, porphyrilic

didymic, norstictic

Atranorin, barbatic

Atranorin, barbatic

isousnic, usnat

Atranorin, nephroarctin, Foliose

friedelin,

merochlorophaeic,
Foliose

Foliose 
atranorin, norstictic,

Phaeographis dendritica

Phaeographis sp.1

Phaeographis sp.2

Physcia dimidiata (Arn.) Nyl

Physcia sp.1

Physcia sp.2

(aphidaceae

raphidaceae

Graphidaceae

Physciaceae

Physciaceae

Physciaceae

Graphidaceae

Lecidaceae

Lecideaceae

Physciaceae

Porpidia irigina

Porpidia sp.
Pyxine sp.1

Pyxine sp. 2

Thecaria quassilicola Fee

Trypethelium $\mathrm{sp} .1$

Physciaceae

Graphidaceae

Trypetheliaceae

Arthoniaceae
Melia azedarach

Leucaena leucocephala

ia mahagoni

Switenia mahagoni

Pinus merkusii, Khaya antothec, Saribus rotundifolius

Pinus merkusii, Khaya antotheca, Gmelina arborea

Euphoria longan, Polyalthia longifolia

Aleurites moluccanus

Toona sureni

Pterocarpus indicus, Switenia mahagoni

Gmelina arborea, Leucaena leucocephala, Toona sureni

Gmelina arborea, Euphoria longan

Pterocarpus indicus, Leucaena leucocephala, Annona muricata Ceiba petandra, Annona muricata, Tectona grandis
Lirallae

Lirallae

Soredia

Soredia

Soredia

Atranorin

Crustose

Crustose

Atranorin $\quad$ Crustose

Crustose

Atranorin, physodic Foliose

Miriquidic, chloroatranorin Foliose

Schizopeltic, physodic, Foliose

usnat, retigeric, ursolic,

leucotylin

Lirellae

Atranorin

Crustose

Apothecia

Atranorin

Crustose

Apothecia - $\quad$ Crustose

Apothecia - $\quad$ Foliose

Soredia Chloroatranorin, $\quad$ Foliose

Atranorin

Crustose

Apothecia Gyrophoric, atranorin Crustose

Apothecia $\quad \begin{array}{ll}\text { Gyrophoric, atranorin } & \text { Crustose }\end{array}$




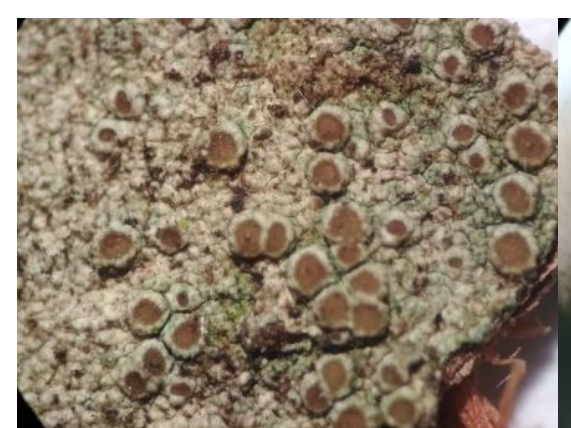

A

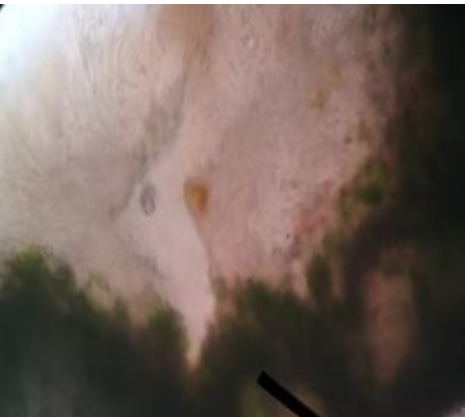

B

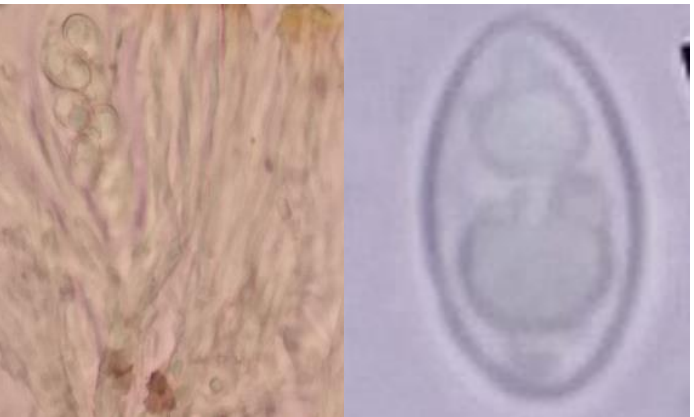

C

D

Figure 3. Lecanora helva Stizenb.: A. Morphological appearance, B. Apothecia Section, C. Ascus, D. Spore

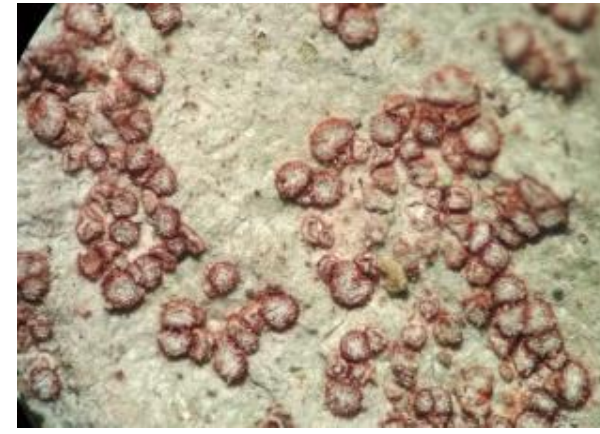

A

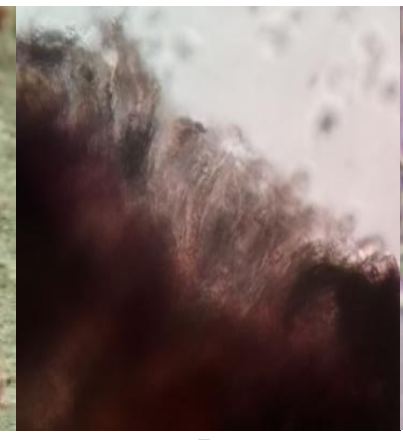

B

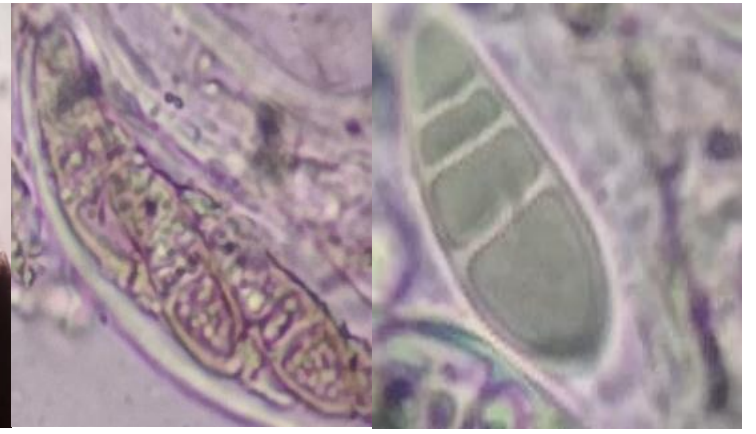

C
D

Figure 4. Arthonia antillarum (DC.) Walf.: A. Morphological appearance, B. Apothecia Section, C. Ascus, D. Spore

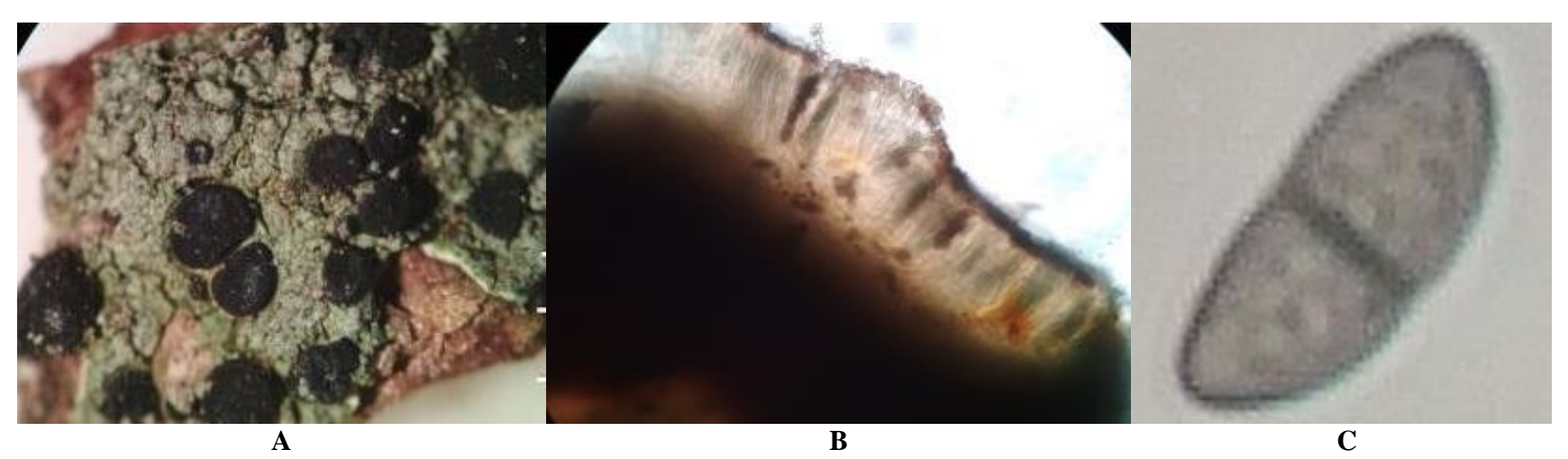

Figure 5. Amandinea melaxanthella (Nyl) Marbach: A. Morphological appearance, B. Apothecia section, C. Spore

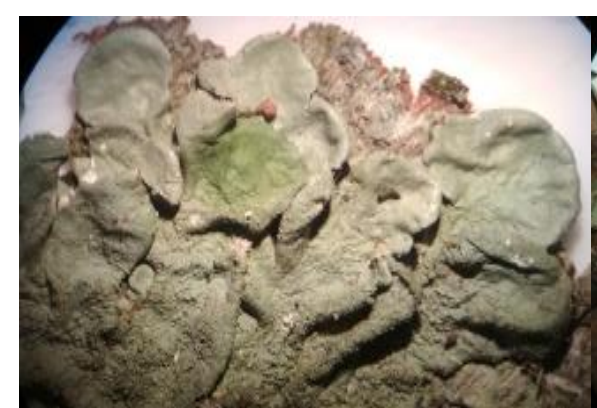

$\mathbf{A}$

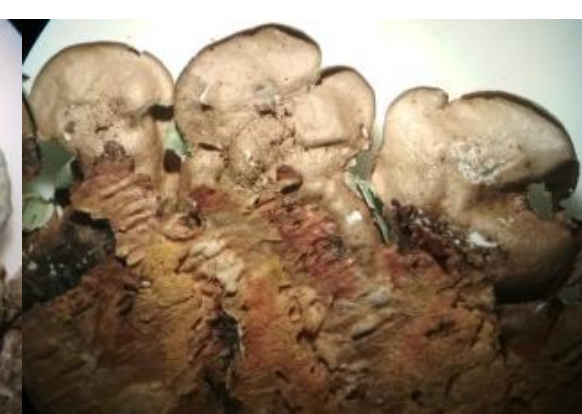

B

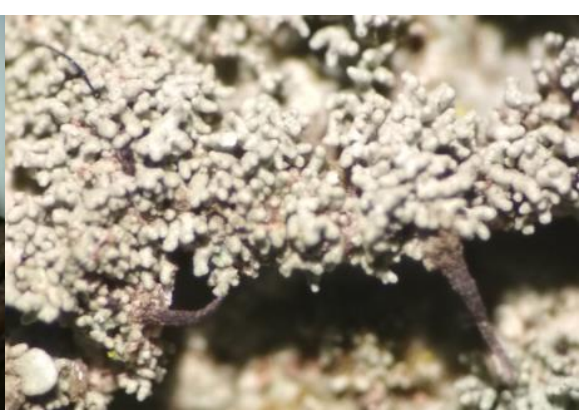

C

Figure 6. Parmotrema tinctorum (Despr. Ex Nyl) Hale. A. Upper surface appearance, B. Lower surface, C. Isidia 


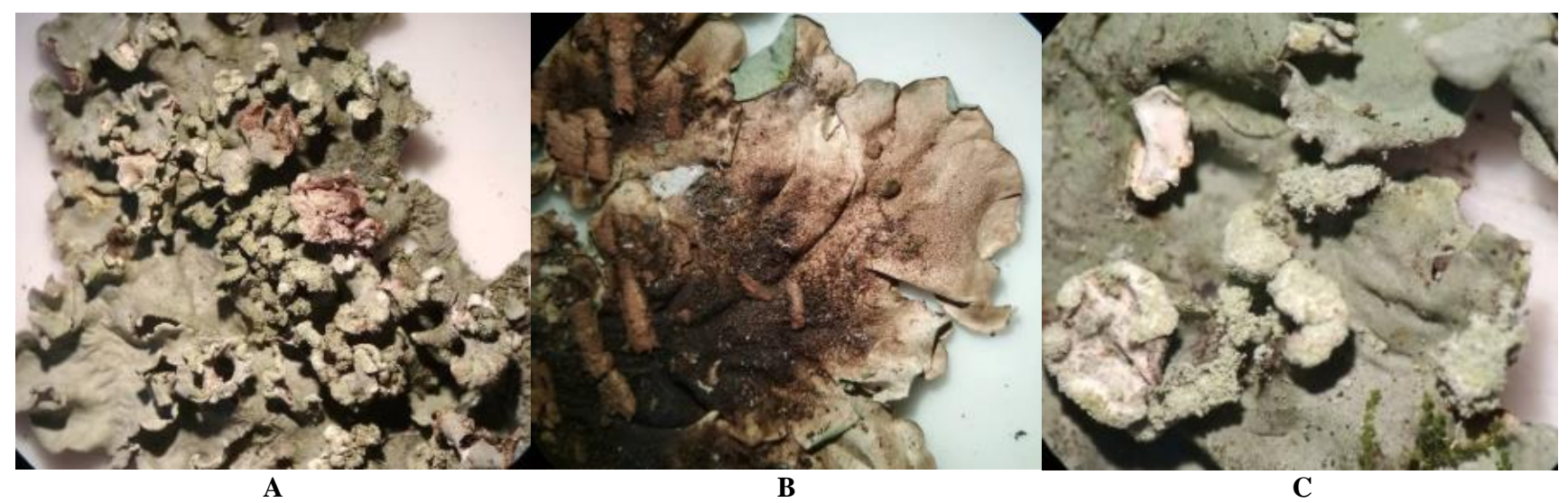

Figure 7. Parmotrema praesorediosum (Nyl) Hale: A. Upper surface, B. Lower surface, C. Isidia

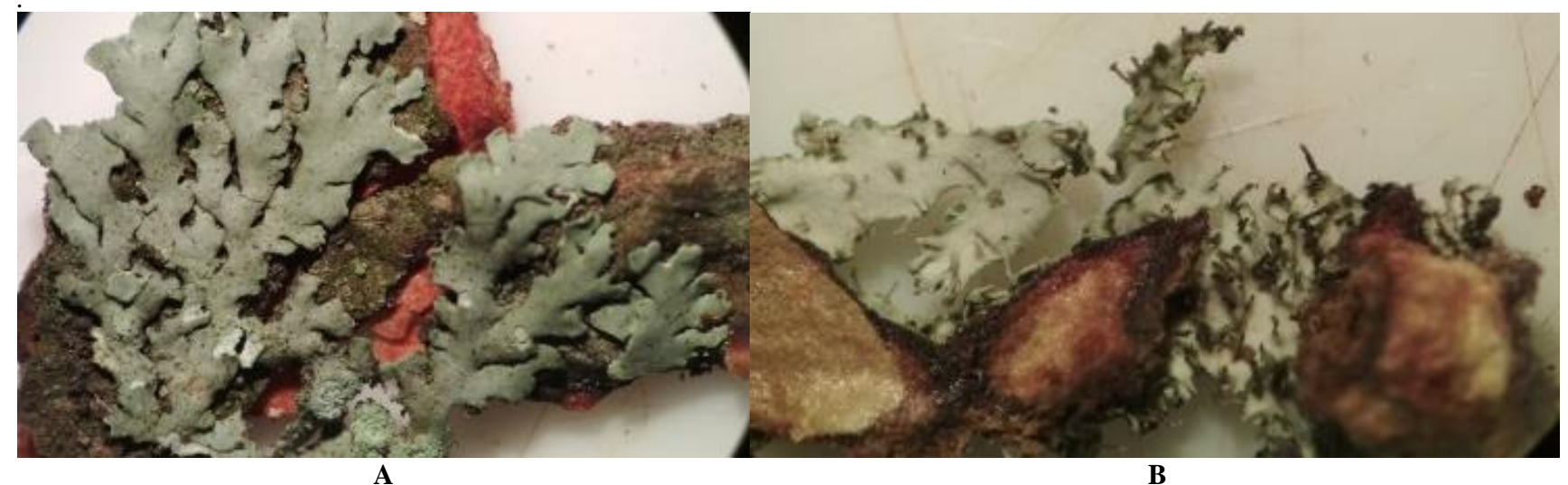

Figure 8. Heterodermia obscurata Nyl.: A. Upper surface, B. Lower surface

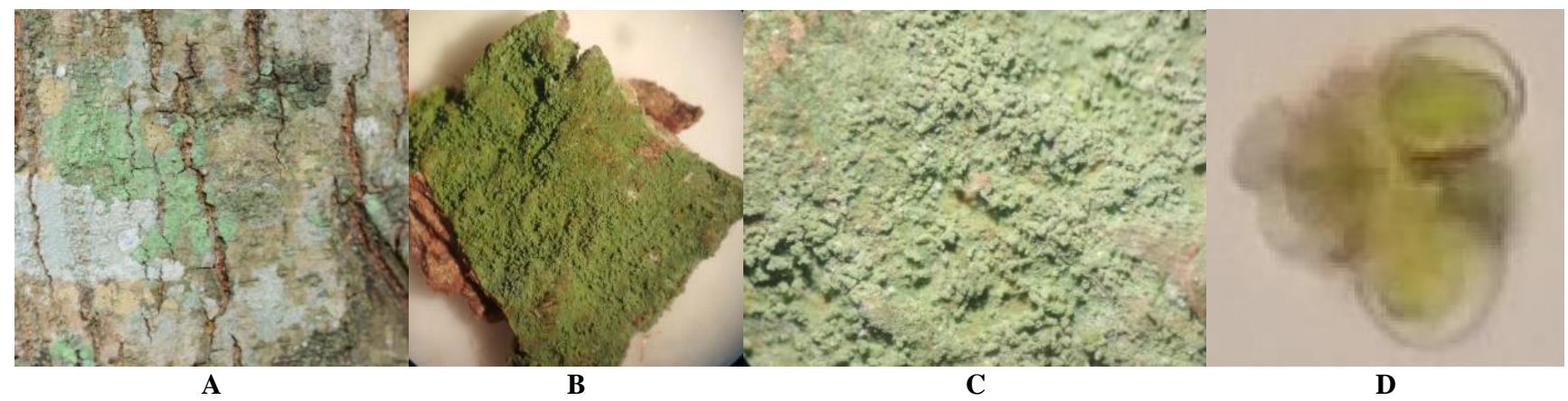

Figure 9. Lepraria incana (L.) Ach.: A. Thallus on substrate, B. Morphological appearance, C. Powder, D. Algae

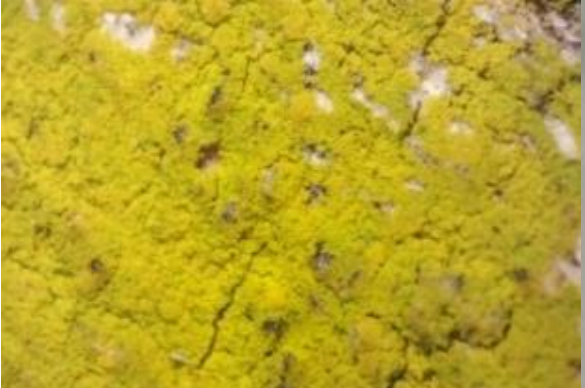

A

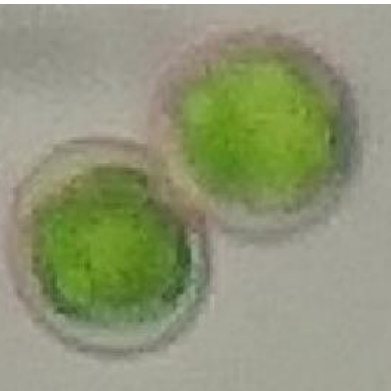

B

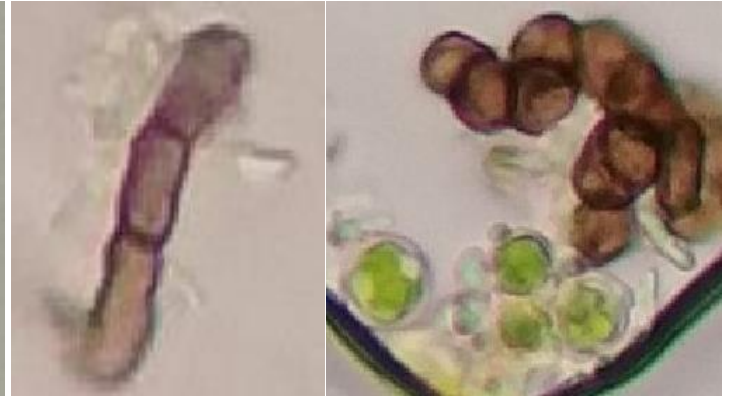

C

Figure 10. Lepraria candelaris (L.) Fr., Nov. Sched. Critic.: A. Upper surface, B. Trebouxia sp. (photobiont), C. Trentepohlia sp. (photobiont), D. Gleocapsa sp. (photobiont) 


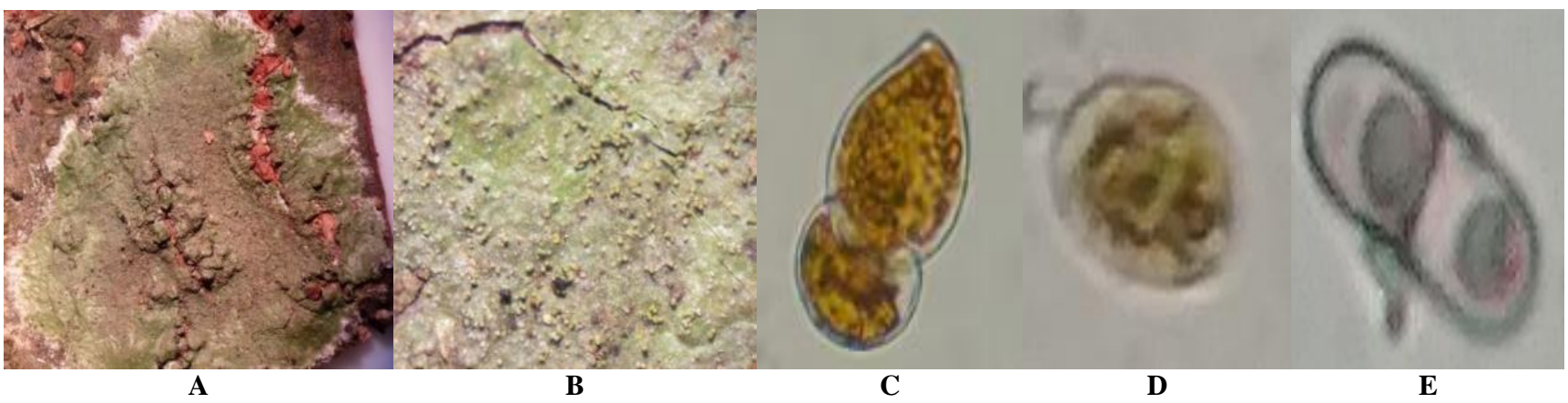

Figure 11. Cryptothecia Stirt.: A. Thallus on substrate, B. Morphological appearance (powdery), C-D. Algae, E. Spore

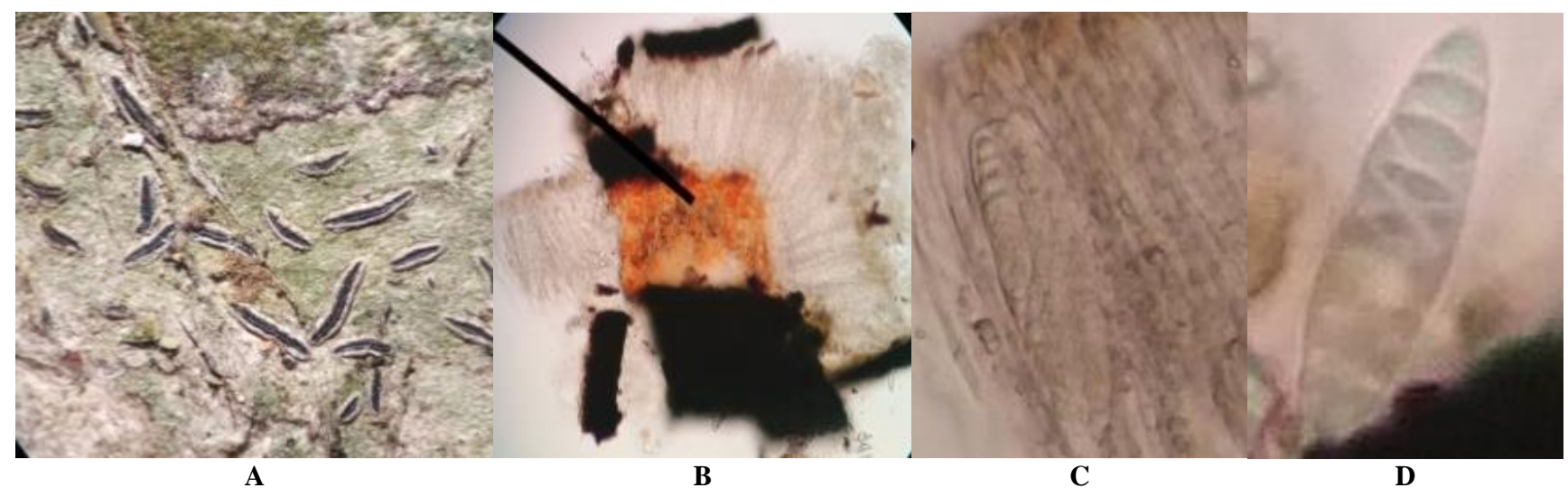

Figure 12. Graphis emersa Mull. Arg.: A. Morphological appearance, B. Apothecia section, C. Ascus, D. Spore

\section{ACKNOWLEDGEMENTS}

Firstly, the authors wish to thank David Hawkswort, $\mathrm{H}$. Kashiwadani, K.H. Moon, Brodo, Felix Schumm and Andre Aptroot for introducing them to lichenology and giving the literature sources. We also wish to thank to the Dean of the Faculty of Mathematics and Natural Sciences, Padjadjaran University who had given the opportunity and convenience of researchers to carry out this research. The financial support received from the Director of BPPTN and Society of Padjadjaran University without which this work could not have been accomplished is gratefully acknowledged.

\section{REFERENCES}

Aptroot A, van Herk CM. 2007. Further evidence of the effects of global warming on lichens, particularly those with trentepohlia phycobionts. Environ Pollut 146: 293-298.

Brodo IM, Sharnoff SD, Sharnoff S. 2001. Lichens of North America.Yale University Press, New Haven.

Caceres MES, Lücking R, Rambold G. 2007. Phorophyte specificity and environmental parameters versus stotochasticity as determinants for species composition of corticolous crustose lichen communities in the atlantic rain forest of Northeastern Brazil. Mycol Progress 6: 117-136.

Caceres MES, Lücking R, Rambold G. 2008a. Corticolous microlichens in Northeastern Brazil: habitat differentiation between Coastal Mata Atlantica, Caatinga and Brejos de Altitude. Bryologist 111: 98-117.

Caceres MES, Lücking R, Rambold G. 2008b. Efficiency of sampling methods for accurate estimation of species richness of Corticolous microlichens in the atlantic rainforest of North Eastern Brazil Gerhard Rambold. Biodivers Conserv 17: 1285-130
Debolt AM, Rosentreter R, Martin EP. 2007. Macrolichen diversity in subtropical forests of North-Central Florida. Bryologist 110: 254-265.

Feuerer T, Hawksworth DL. 2006. Biodiversity of lichens, including a world-wide analysis of checklist data based on Takhtajan's floristic regions. Biodivers Conserv 16: 85-98.

Gradstein SR, Nadkani NM, Kromer T, Holtz I, Noske N. 2003. A protocol for rapid and representative sampling of non-vascular epiphyte diversity of tropical rain forests. Selbyana 24 (1): 105-111.

Hale ME. 1974. New combination in the lichen genus Parmotrema Massalongo. Phytologia 28 (4): 334-339.

Holz I, Gradstein SR. 2005. Cryptogamic epiphytes in primary and recovering upper montane oak forests of Costa Rica, species richness, community composition and ecology. Plant Ecol 178: 89-109.

Huneck S, Yoshimura I. 1996. Identification of Lichen Substances. Springer, Berlin.

Kershaw, K.A. 1985. Physiological ecology of lichens. Cambridge Univ.Press, Cambridge.

Komposch H, Hafellner J. 2000. Diversity and vertical distribution of lichens in Venezuelan tropical lowland rain forest. Selbyana 21 (1-2): 11-24.

Krik PM, Cannon PF, Minter DW, Stalpers JS. 2008. Ainsworth and bisby's dictionary of the fungi, 10th ed. CABI Publishing, Wallingford, UK.

Kumar B. 2009. Macrolichens cover and their distribution pattern on two common phorophytes (Quercus semecarpifolia and Rhododendron arboreum) in a temperate forest of Rudraprayag District Grahwal (Uttrarkhand), India. Nat Sci 7 (3): 13-16.

Kusmoro J, Noer IS, Jatnika MF, Permatasari RE, Partasasmita R. 2018. Lichen diversity in geothermal area of Kamojang, Bandung, West Java, Indonesia and its potential for medicines and dyes. Biodiversitas 19 (6): 2335-2343

Lucking R, Archer AW, Aptroot A. 2009. A world-wide key to the genus Graphis (Ostropales Graphidaceae). Lichenologist 41 (4): 363-452.

Lücking R, Matzer M. 2001. High foliicolous lichens alpha-diversity on individual leaves in Costa Rica and Amazonian Ecuador. Biodiver Conserv 10: 2139-2152 
Lücking R, Rivas Plata E, Chaves JL, Umaña L, Sipman HJM. 2009. How many tropical lichens are there... really? In: Thell A, Seaward MRD Feuerer T. (eds.). Diversity of Lichenology - Anniversary Volume. Bibl. Lichenol 100: 399-418.

Lücking R. 1999. Ecology of foliicolous lichens at the "Botarrama" trail (Costa Rica), a neotropical rain forest. I. species composition and its ecogeographic implications. Biotropica 31(4): 553-564.

Lucking R. 2009. The taxonomy of the genus Graphis sensu Staiger (Ascomycota: Ostropales: Graphidaceae). Lichenologist 41 (4): 319 362 .

Lumbsch HT, Ahti T, Altermann S, Amo G, Aptroot A, Arup U, et al 2011. One hundred new species of lichenized fungi: a signature of undiscovered global diversity. Phytotaxa 18: 1-127.

McCune B. 2000. New Frontiers in bryology and lichenology, lichen communities as indicators of forest health. Bryologist 103 (2): 353 354.

Nash III TH. (ed.) 2008. Lichen biology. Cambridge University Press, UK.

Noer IS. 1989. Lichen and air pollution in Kamojang Geothermal area West Java Indonesia. Institute of Ecology Padjadjaran University and Kershaw KA. 1985. Physiological ecology of lichens. Cambridge Univ. Press, Cambridge.

Obermayer H. 2002 Management of a lichen herbarium, in: Kranner Beckett RP, Varma AK, eds Protocols in Lichenonology, Springer, Berlin.

Odum EP. 1993. Basics of Ecology. Tjahjono Samingan's translation. 3rd ed. Gadjah Mada University Press, Yogyakarta. [Indonesian]

Pitakpong A, Naksuwankut K, Sumanwaree P, Muangsan N. 2016. The study distribution of lichen genus graphis (grahidaceae) in Thailand.
Proceeding of the $3^{\text {rd }}$ National Meeting of Biodiversity Management in Thailand. 3: 142-148. June 15-17. Na Province Thailand.

Purvis W. 2000. Lichens. Smithsonia Institution Press, Washington DC. USA in Association with The Natural History Museum, London.

Richardson DHS. 1992. Pollution monitoring wit lichens. Richmond Pub. Co. Slough, England.

Rivas Plata E, Lumbsch HT, Lücking R. 2012. A new classification for the lichen family Graphidaceae s.lat. (Ascomycota: Lecanoromycetes: Ostropales). Fungal Divers 52: 107-121.

Rogers RW. 1992. Lichen photobiont. Flora of Australia 54: 19-22.

Schumm F. Aptroort A. 2010. Seychelles Lichen Book. Mozartstr.D73117 Wangen. Deutschland.

Sipman HJM, Aptroot A. 2001. Where are the missing lichens? Mycol Res 105 (12): 1433-1439.

Staiger B. 2005. How to arrange the diversity of a tropical lichen family? Systematics and generic concept in the lichen family graphidaceae. Arch Sci 58: 53-62

State G, Popescu IV, Gheboianu A, Radulescu C, Dulama I, Bancuta J, Stirbescu R. 2010. Lichens as biomonitors of heavy metal air pollution in the Targoviste area. J Sci Arts 1 (12): 119-124.

Vicol I. 2016. Ecological patterns of lichen species abundance in mixed forests of Eastern Romania. Ann For Res 59 (2): 237-248.

Will-Wolf S, Hawksworth DL, McCune B, Rosentreter R, Sipman HJM. 2004. Lichenized fungi. Mueller MG, Bills GF, Forster MS. (eds.). Biodiversity of fungi: inventory and monitoring methods. Elsevier Academic Press, Burlington, USA.

Zahlbruckner A. 1843. Lichen flora of Java, supplemented and published by Fr Mattick, Berlin Dahlem. [Ducth] 